\title{
FEMALE DIRECTORS ON BOARDS. THE IMPACT OF FAULTLINES ON CSR REPORTING
}

\begin{abstract}
Purpose: This paper analyzes the role of female directors on CSR disclosure. It assumes the existence of faultlines when studying gender diversity and classifies female directors into three categories: industry experts, advisors, and community leaders. It also examines the influence of the power of female directors as a moderator on the association between female director categories and CSR disclosure.
\end{abstract}

Design/methodology/approach: The paper is based on a dynamic Generalized Method of Moments panel estimator which allows the control of unobservable heterogeneity and endogeneity and reduces estimation bias.

Findings: Results confirm the double-sided nature of gender diversity, noting different behavior among female directors according to their experience and backgrounds. Moreover, the dominating owner position of female directors can balance and moderate the effect of female directors appointed for their technical knowledge or political and social ties. The results also confirm the necessity to not consider all women directors as a homogeneous group and explore the influence and interrelations of female faultlines on CSR disclosure.

Practical implications: The paper highlights the need to consider the specific skills, expertise, and connections of female board members when analyzing the effect of board composition, and supports the view that firms should emphasize the unique human and social capital of directors to understand how boards impact on firm strategies. Specifically, we support the recommendations of the European Commission (2011) regarding the need to increase skills and expertise when selecting new non-executive female board members.

Social implications: At a time when most governments are introducing active policies that require firms to nominate women to boards, the understanding of the consequences of women's presence on boards and the interrelations between female power and the diverse categories of female directors is timely and important.

Originality/value: This is the first paper that provides empirical evidence to the scarcelystudied area of the human and social capital of female directors' roles in CSR disclosure, providing an alternative view of the role of women in corporate board effectiveness.

Keywords: gender, CSR disclosure, faultlines, experience, power 


\section{INTRODUCTION}

Literature on gender diversity and CSR has usually reported a positive influence of female directors on CSR practices (Bear et al., 2010; Setó-Pamies, 2015; Cuadrado-Ballesteros et al., 2017), arguing that women are more sensitive to social needs, more aware of others, and more stakeholder-oriented than men, as well as being more concerned about ethical issues (Tate and Yang, 2015; Rao and Tilt, 2016). However, previous literature on gender diversity usually examines the mere presence of women directors without analyzing differences among women. The paper by Adams (2016) opens the door on this gap in the literature and argues the need to better understand what female directors bring to boardrooms. After the recent economic crisis, the inclusion of directors with specific knowledge and experience on boards has also become a frequent recommendation (de Andrés et al., 2018). We advance on the premise that women's attitudes towards CSR can be affected by individual differences in personal styles, skills, connections, and business knowledge (Hambrick and Mason, 1984), noting that it is necessary to go beyond gender and consider other female qualities when analyzing gender effects on company outcomes. In addition, we also suggest that when studying the role of gender diversity in firm outcomes, it is important to consider the moderating role of female director power because it can highly condition female influence over team decisions.

Considering the above, the main purpose of this paper is to analyze the role of the social and human capital of female directors on CSR disclosure. We first use the board classification of Hillman et al. (2000) and classify female directors into three main categories: industry experts, advisors, and community leaders, according to their business, technical expertise, or political and social ties, respectively. Then, we use resource dependence, the gender socialization theory, and the faultline theory to explain the impact of these categories of female directors on CSR disclosure. As a second objective, we examine the influence of female directors' power as a moderator on the association between the board gender diversity and CSR 
disclosure. In summary, this paper addresses the following questions: Do female directors promote CSR disclosure differently according to their knowledge, expertise, and ties? How can female power moderate the influence of female directors on CSR disclosure?

We focus on Spain, where we examine a sample of Spanish listed firms during the period of 2008-2014. Spain is an interesting country in which to study the role of board characteristics in gender-diverse boards due to several factors. First, at the time of the study, the Conthe Code (2006) recommended a balance of gender on boards, being the first time that a recommendation on gender diversity had been explicitly included in Spain. Second, Spain is a very interesting country in which to examine the Hillman categorization of boardrooms and the specific role of female directors with political connections due to the fact that Spanish boardrooms have a high number of directors with political connections, mainly explained by the high number of privatizations carried out in Spain during the last few decades (Bona-Sánchez et al., 2014). Finally, because of the high concentration of ownership of Spanish firms and the relevance of institutional investors in this country (Bona-Sánchez et al., 2018), the analysis of the ownership power of female directors is a very interesting issue.

Our findings suggest that companies characterized by female directors with technical expertise are effective at pursuing CSR disclosure strategies. Results also confirm the two-sided nature of gender diversity, demonstrating that female directors with political and social connections reduce CSR transparency. In addition, the positive effect of advisors and the negative effect of politically and socially connected female directors are both reduced in the presence of female power in the company, suggesting that the dominating owner position of female directors can balance and moderate the effect of female directors appointed for their technical knowledge or political and social ties. Overall, the results suggest that board gender diversity is two-sided because it can propel or impede CSR disclosure, depending on the expertise, technical knowledge, network, and power of female directors on the board. 
This study contributes to previous research in several ways. First, this is the first paper that highlights the different roles of women directors in CSR disclosure, depending on their knowledge, technical expertise, or connections. Particularly, this study confirms that not all women directors are equally effective in improving CSR disclosure, and that some female directors, especially community leaders, can reduce it. Second, this paper contributes to the literature on politically connected firms, shedding light on the limited empirical evidence of the effects of political ties on CSR reporting. Third, the paper highlights the need to consider the specific skills, expertise, and connections of board members when analyzing the effect of board composition, and supports the recommendations (European Commission, 2011, p. 7) regarding the need to increase skills and expertise when selecting new non-executive board members. Finally, this is the first paper that associates female power with board gender diversity, noting how the effect of women directors on CSR disclosure is highly conditioned by the ownership power of women directors.

\section{THEORETICAL FRAMEWORK AND HYPOTHESES}

\subsection{Theoretical background}

Board diversity generally refers to the ethnicity, race, nationality, and gender of boards of directors (e.g., Ruigrok et al., 2007). However, the notion of board diversity might be viewed as the mixture of several factors on boards, rather than disparity (men/women) or geographic characteristics, such as board members' different skills, education, expertise, or knowledge of other industries, among other things (Nekhili and Gatfaoui, 2013; Pechersky, 2016). When board directors provide expertise, background, knowledge, or skills, for instance, they are supplying human capital to the board. When directors are capable of obtaining external resources and maintaining ties with external organizations, they are providing social capital, as Hillman and Dalziel (2003) and Haynes and Hillman (2010) argue. 
Reviews of diversity research conclude that it is often associated with positive cognitive and signaling consequences (e.g. better image and reputation, innovation, or creativity). In diverse boards, their directors can be men or women, external or executive, with more or less experience, or from different professional backgrounds. These are called faultlines (Lau and Murnighan, 1998). Among all board diversity attributes, the combination of board gender diversity (women directors on boards) and board's characteristics merits our attention, since it is relevant to the exploration of how the social and human capital of female directors on boards affects CSR reporting.

According to the resource dependency theory, the board of directors is a significant tool for allocating external resources and for maintaining ties with external organizations. This approach claims that when board directors provide image, expertise, background, reputation, capabilities, and outside links with other firms, they perform their duties and tasks more efficiently. Thus, a board's social and human capital might have a positive impact on strategic business decisions such as encouraging CSR disclosure (e.g., Wang and Dewhirst, 1992; Pechersky, 2016). Additionally, both types of capital (social and human) on boards provide other relevant benefits to firms, because boards may play a significant advisory role (Dass et al., 2014) and because each board member provides his/her individual professional background and expertise. If they are outsiders, they can bring reputation, outside connections, and engagement from outside agents (e.g., Pfeffer and Salancik, 1978; Baysinger and Butler, 1985). Hence, firms with diverse boards will enhance the flow of information by better affecting the decision-making process. These companies will therefore be more likely to disclose CSR matters since this may strengthen links and relations with external stakeholders and organizations. Furthermore, also drawing from a resource dependence perspective, the presence of women directors on boards will provide positive benefits to firms because these directors will bring individual and particular backgrounds, skills, knowledge, and expertise to the 
decision-making process, and will be able to solve problems better than male directors (Pechersky, 2016). In this regard, Mallin and Michelon (2011), who also draw on the resource dependence approach, claim that female directors, as suppliers of relational and human capital, might improve companies' social outcomes such as CSR reporting, as well as their image and reputation, maintaining ties and connections with companies' stakeholders. Therefore, according to the resource dependence theory, women directors on boards will be more likely to promote the reporting of CSR issues.

The gender socialization theory (sociological, cognitive, and psychological perspectives) argues that women's leadership style is different from that of male directors (Alonso-Almeida et al., 2015). The leadership style of women directors is distinguished by their tendency to be more sympathetic, more receptive, more caring, and more cooperative (e.g., Kim, 2013). Female directors also show more responsible behavior and a more sensitive attitude to CSR matters, given their sympathy for non-profit issues, training, laws, and rules (e.g., Bear et al., 2010; Harjoto et al., 2015; Landry et al., 2016).

Finally, the faultline perspective states that a group or team can be split into homogeneous subgroups which are based on the alignment of the members' attributes (Bezrukova et al., 2009; Lau and Murnighan, 1998, 2005; Li and Hambrick, 2005; Pearsall et al., 2008). Therefore, women directors should not be considered as a homogeneous group, since it is necessary to consider the differences among them according to their characteristics (i.e existence or not of technical experience, business background, or political ties). As Lau and Murnighan (2005) argue, members' group-related identities have more to do with their subgroups than with their entire groups. Therefore, we hypothesize the existence of faultlines among industry experts, advisors, and community leader female directors, since these categories of directors share human and social capital values. 


\subsection{Hypotheses development}

\subsubsection{Female Industry Experts and CSR disclosure}

Decisions such as CSR reporting might be influenced by the different capabilities, skills, backgrounds, professional experience, and ability to solve problems of external directors (Baysinger and Zardkoohi, 1986). According to the background and prior expertise provided by each board director, they can be categorized in three ways: as industry experts, advisors, and community leaders. This classification is based on the taxonomy of directors' resource dependence roles proposed by Hillman et al. (2000), which is also used by authors such as Markarian and Parbonetti (2007), Bear et al. (2010) and Haynes and Hillman (2010), among others.

Board directors who provide their past expertise, capabilities, and the professional background acquired in other companies as executives to the boards on which they have sat are defined as industry experts (Hillman et al., 2000). The human capital supplied by industry expert directors might result in benefits for companies, affecting the decision-making processes and board performance. In addition, they might identify risks and opportunities for the business, given their professional background and the expertise previously acquired as insiders of other organizations (Dass et al. 2014; Faleye et al., 2014).

This perspective is also suggested by Westphal (1999) and Shropshire (2010), among others. They draw on the resource dependence approach to claim that industry expert directors are able to provide improved human and social capital to boards. This may be due to their prior expertise, knowledge, and professional backgrounds from other organizations; all of which might promote CSR reporting. The above arguments and views are supported by prior empirical research (e.g., Walls and Hoffman, 2013; Ben Barka and Dardour, 2015). This past evidence reports that companies with better environmental and social performance have board directors with expertise, professional backgrounds, and knowledge. Specifically, industry expert 
directors are positively associated with environmental and social issues. Thus, boards made up of industry expert directors might encourage CSR disclosure, which would be positively valued by shareholders and stakeholders. However, among all the industry expert members, the role played by female industry expert directors merits our attention, given, to the best of our knowledge, the lack of research on this topic.

In this regard, Singh et al. (2008) argue that women directors usually acquire board expertise from small companies and do not tend to have previous experience as COOs or CEOs. The gender socialization theory also stresses some qualities of women which cause female leadership to differ from that of their male counterparts. Among these characteristics, the educational and professional backgrounds of women and men directors are different. As Hillman et al. (2000) support, female directors increase board expertise principally for two reasons. Firstly, because they have advanced degrees and their prior occupational experience and backgrounds come from outside the area of business, and secondly, because they are generally more oriented toward social and environmental issues. Thus, boards with women directors that provide social and human capital such as education and knowledge focused on social matters, may diversify the board and bring broader views and opinions. Accordingly, boards with female industry expert directors might be more likely to engage with stakeholders' interests and needs, and they will show a more positive attitude toward disclosing CSR information. Shrader et al. (1997) also posit that human capital provided by women directors on boards will be beneficial because they will aid in solving problems among board members. Furthermore, Giannarakis (2014) claims that past experience provided by female directors on boards results in more diverse and unique leadership styles and perspectives in comparison to their male counterparts, which might promote CSR reporting.

Hence, based on the above perspectives, we predict that women directors on boards with prior expertise, skills, and background will have greater orientation toward stakeholders and 
social issues. Thus, they will be more likely to support CSR reporting. In this regard, we propose the following hypothesis:

H1: Female industry expert directors on boards are positively associated with CSR disclosure.

\subsubsection{Female advisors and CSR disclosure}

Advisor directors differ from industry experts because the former allocate particular skills, experience, and backgrounds in fields such as financial issues, different sectors, or environmental and social matters to boards (Shaukat et al., 2016). This is in line with the description of advisors given by Hillman et al. (2000), who are defined as board members supplying particular past occupational backgrounds and experience. This human capital was gained when these directors developed their roles as insiders in auditing, accounting, financial, marketing, and consulting companies. This specific human capital is expected to have a positive effect on strategic decisions like CSR disclosure. However, in comparison to industry expert directors, who have general expertise in management issues, advisors do not (e.g., Hillman et al., 2000).

The particular expertise, and occupational backgrounds allocated to boards by advisor directors allows them to make relevant decisions on strategic issues not associated with markets or business, and in line with CSR disclosure (Knonrad et al., 2006; Galbreath, 2016). Consistent with this idea, Helfaya and Moussa (2017) report that directors with financial expertise in audit committees are more likely to report sustainability and environmental information. But how women advisors on boards behave regarding CSR disclosure is a question which still remains unclear.

According to Adams and Ferreira (2009) the mere presence of female directors on boards is not sufficient to impact on business decisions, but board gender diversity must also 
exist in a qualified board. This means, for example, that women directors should have significant and specific expertise as senior officers, or individual backgrounds or skills which empower them to impact on the decision-making process, as Smith and Parrota (2018) suggest. Therefore, the specialized expertise of female advisors shows an orientation toward social and environmental issues, rather than toward financial, business, and market matters. This provides diverse resources of human and social capital to boards, and, consequently, they will be more likely to give counsel on CSR matters and affect strategic decisions such as CSR reporting (Galbreath, 2016).

Rosener (1995) also posits that females possess more specific ability in social relations than males, and show a higher commitment and engagement with the needs and demands of others, in line with female advisors' attributes. Boards with women who are sensitive toward others will be better able to become involved with their socials needs and demands and to support decisions concerning CSR disclosure (Konrad et al., 2006).

Accordingly, boards with specific resources provided by female advisors are presumed to be more involved with CSR policies and activities such as CSR disclosure. The particular skills and orientations of this type of woman director are also expected to produce empathy with different stakeholders' needs and demands, such as social and environmental matters. Thus, women advisors on boards are more likely to encourage the reporting of CSR information. In this regard, we suggest the following hypothesis:

H2: Female advisor directors on boards are positively associated with CSR disclosure.

\subsubsection{Female community leaders and CSR disclosure}

When directors are community leaders, they provide resources such as social standing, reputation, legitimation, or close relations with relevant stakeholders (Dang et al., 2014). Hillman et al. (2000) state that community leader directors have experience and professional 
backgrounds which they acquired when they developed their tasks in organizations or communities such as political parties or social organizations. This means community leaders serving on boards may maintain links and relations with non-business or social communities. Most community influentials on boards are ex-politicians or have held a relevant position in a significant community. In this regard, these directors are well-known, valued, and have influence in non-profit environments (Li et al., 2008).

Community influentials can be considered to be significant providers of social capital, because they are able to provide credibility, transparency, and significant external relations with other organizations. This perspective is also suggested by Tsai and Ghoshal (1998), Hillman and Dalziel (2003) and Chen (2014), who argue that the role played by community leader directors on boards is to supply resources (social capital) from external communities and organizations. Furthermore, Tian et al. (2011) show that community leaders serving simultaneously on several boards allocate significant social capital by maintaining contacts with other board members, as Kor and Sundaramurthy (2009) and Ortiz-de-Mandojana et al. (2012) also report. In comparison to advisors, community leaders can be appointed on boards without having professional backgrounds in business or accounting, or financial knowledge. For this reason, the presence of community leaders or community influentials on boards is so high (e.g., Braiotta and Sommer, 1987; Peterson and Philpot, 2007).

Female community influentials will be better able to maintain networks with other organizations and interact with other board directors. This might lead companies to gain several benefits, not only focused on acquiring resources, but also on a better monitoring, viewpoint, and orientation toward more social and environmental matters. In this regard, Nielsen and Huse (2010) show that female directors are usually more tolerant than male directors. This can be due to the fact that they accept the positions and opinions of others, are involved with the problems of others, support others, and tend to solve interpersonal and relational matters. The 
authors suggest that "women may be particularly sensitive to - and may exercise influence on - decisions pertaining to certain organizational practices, such as corporate social responsibility and environmental politics"' (Nielsen and Huse, 2010, p. 138).

Past research conducted by Harrigan (1981) and Kesner (1988) reported that the education of women directors was more connected to non-profit or educational fields than that of men directors. Sometime afterwards, Hillman et al. (2002) also demonstrated that women directors appointed as community leaders have non-CEO backgrounds, given that their expertise comes from financial institutions, law, educational organizations, and government. In line with Hillman et al. (2002), women community leaders will bring non-business approaches and views to the decision-making process, in addition to power, outside ties, and experience related to influential collectives in the community. These arguments and evidence seem to support the idea that female community leaders might be board members sensitive to CSR issues, and therefore be useful for allocating a social approach to boards when addressing CSR disclosure.

However, in most Spanish boards, directors serving as community influentials have been politicians or still have personal ties with political parties. These political links are negatively perceived by shareholders and stakeholders, and as a result, their perspectives and opinions concerning companies where these directors serve tends to be negative. In general terms, politicians or ex-politicians, particularly in Spain, are seen by society as being corrupt and bad managers. In addition, they are considered to be individuals who take advantage of their influence to do business, or benefit at citizens' expense. In this regard, Chen et al. (2011) support this thesis by reporting that boards with a high presence of community leader directors with political ties prevail in companies domiciled in environments where corruption takes place. This seems to suggest that community influentials with political connections may employ these political resources in order to gain personal benefits. Accordingly, these community leader 
directors will be less likely to support the reporting of CSR information (Bona-Sanchez et al., 2014). Furthermore, these connected firms could reduce the disclosure of CSR information if they feel less sensitive to market pressure (Chaney et al., 2011).

These arguments could lead to the supposition that community leaders with political connections will not encourage CSR disclosure. Concerning female community leaders with political connections, as far as we know there is no past research exploring their relationship with CSR reporting. However, we extend the perspectives and ideas provided for the whole group of community leaders with political ties to the role performed by women with political links. Although there is evidence showing that the leadership styles of women and men are different (e.g., Alonso-Almeida et al., 2015) and, consequently, might affect CSR reporting in a different way, society and stakeholders' scrutiny of directors with political connections will be the same for men and women. Politicians are stigmatized by society and stakeholders, irrespective of whether they are females or males since the mere fact of being a politician is negatively perceived by society, as suggested above (see Mavin et al., 2010, for a more in-depth review).

We predict that female community leader directors will have a negative impact on CSR reporting. Accordingly, drawing on the above views, we propose the following hypothesis:

H3: Female community leader directors on boards are negatively associated with CSR disclosure.

\subsubsection{The moderating role of institutional female directors}

When conducting research that analyzes the relationship between corporate governance and CSR disclosure, it becomes relevant to adopt a holistic approach (Jain and Jamali (2016). This allows us to explore how different interactions among distinct corporate governance mechanisms affect CSR reporting. Corporate governance mechanisms should be considered "as 
bundles rather than piecemeal" (Jain and Jamali, 2016), and the examination of the effects of all corporate governance dimensions on CSR outcomes, such as CSR disclosure, should merit our attention.

According to Triana et al. (2013), the effect of women directors on firm outcomes is highly conditioned by the power of women directors; defined as the ability to influence decisions. One of the main dimensions of this female power is ownership power. Daily and Johnson (1977) note that women have greater influence when they hold a large shareholding position. In this regard, we suggest interdependency between institutional female directors who represent dominant shareholders with significant ownership concentration on Spanish boards and the role of female directors on CSR disclosure, drawing on a holistic approach. The amount of stocks held by female institutional investors will give rise to changes and affects the decisionmaking process through their voting blocks, as well as causing them to play a more active or passive role as shareholders. According to Cornett et al. (2007), dominant shareholders such as institutional investors might have incentives and the power to impact on board composition. Thus, institutional directors may be relevant moderators of the association between board capital and CSR disclosure.

There is scarce literature on the moderating role of institutional investors, and no papers analyze the moderating role of female institutional directors (Guizani, 2013; Che and Zhang, 2017; Oh et al., 2017) In this research, we support the view that institutional investors, and specifically women who represent them, might have a positive or negative moderating role in board characteristics and business outcomes. Specifically, we suggest that the effect of female power is complementary or substitutive depending on the role that women have on boards and depending on the category of female directors on boards. We expect that the positive role of industry experts and advisory female directors will be higher with a high presence of powerful females on boards (complementary role). On the other hand, we also expect that the negative 
influence of community leader female directors will be compensated by female directors who represent dominant shareholders, so for this category of women directors, we expect that female power has a substitutive role.

Based on above perspectives, we predict that powerful female institutional directors will influence the effect of the rest of female directors on CSR. Thus, we propose the following hypothesis:

H4: The impact of female industry experts, female advisors, and female community leaders on CSR disclosure is moderated (with a complementary or substitutive role) by the presence of powerful female directors.

\section{DATA AND METHODOLOGY}

The analysis is conducted on 152 non-financial firms listed on the Spanish stock market for the years 2008-2014.

The Global Reporting Initiative (GRI) is an international non-profit organization that helps companies to improve the quality, rigor, and relevance of sustainability reports voluntarily (Fuente et al., 2017). Through a set of global sustainability reporting standards, GRI aims to harmonize the different reporting systems. It allows companies to employ a common language when communicating on their sustainability policies and strategies. The SABI ${ }^{1}$ database provides us with the financial and accounting information. We personally collected information about board characteristics from both the website of the Spanish government agency which is in charge of the financial regulation of the securities markets in Spain (National Securities Market Commission, or CNMV) and from the corporate websites. Our final sample consists of an unbalanced panel with 763 firm-year observations.

\footnotetext{
${ }^{1}$ Iberian Balance Sheet Analysis System which includes general and financial information from the companies listed on the Spanish Companies Registration Office.
} 


\subsection{Variables}

\subsubsection{Measuring CSR disclosure}

To generate the dependent variable, we use the CSR information transmitted by the companies through their corporate reports. Based on previous literature, we use a multidimensional construct in order to gather all the CSR information disclosed by the companies.

Based on this information, an index of the CSR information disclosed by companies is used as dependent variable. The composition of the CSR index is based on the aggregation of the following items (García-Meca and Pucheta-Martínez, 2018; Ramón-Llorens et al., 2018): a) CSR information disclosure which takes the value 1 if the company discloses any social, environmental, or economic information and zero otherwise; b) Informal preparation of CSR reports with non-GRI reports that equals 1 if the company does not report CSR issues using the report recommended by the GRI, but instead uses other types of reports or other ways of reporting different from the GRI suggestions such as their own reports or those on the firm's website, and zero otherwise; c) GRI report, which takes the value of 1 if the company discloses CSR information using only the GRI format and zero otherwise; d) GRI certification is coded 1 if the company presents the CSR report certified by the GRI and 0 otherwise; e) External assurance of the CSR report will take the value 1 if the CSR information disclosed is audited by independent third parties or external bodies and 0 otherwise. External assurance is a vital step for those firms that want to increase confidence, credibility, and reliability in the quality of the CSR content and data disclosed in their report, as it provides an independent, third-party view of the thoroughness and importance of their sustainability systems and approach. In line with Birkey et al. (2016), this kind of assessment allows firms to improve their credibility and reputation because the reported information is usually certified by external and independent providers, such as accounting or consultancy firms or quality assurance consultants, among 
others; and f) Assurance scope, which will take the value 1 if the entire or whole sustainability or CSR report is assessed and 0 otherwise. When the sustainability or CSR report is partially assessed, or only some sections of these reports are assessed, this item will be coded as 0 .

The information for our CSR index was collected from two sources: (1) from the GRI webpage, where companies voluntarily indicate whether they follow the GRI report for disclosing CSR information or if the CSR report's content is certified by the GRI or another external assurance, among others, and (2) from the companies' websites, where firms can provide information about CSR using informal reports (the report does not follow any formal pattern like the GRI report, for instance) or formal reports (the report follows a formal pattern such as the GRI report). We have checked whether each of the items considered in the construction of the CSR index occur in each firm of our sample, assigning 1 point if the item is present and 0 otherwise. Therefore, our CSR index is measured by the unweighted aggregation of these six dummy variables. This way of calculating our CSR index is consistent with past research (Toffel, 2005; Reid and Toffel, 2009; Kayser et al., 2014; Marquis et al., 2016)

It is important to highlight that following the GRI format is recommended but not compulsory for Spanish companies and that sometimes, due to the large number of indicators proposed and the fact that it is quite expensive for companies to prepare the report in accordance with GRI standards, companies tend to reject this framework and present the information in other formats (Bonsón and Bednárová, 2015).

\subsubsection{Independent variables}

The proportion of independent female outsiders categorized as industry experts (IE), advisors (ADV) and community leaders (CL) over the board size serve as the independent variables in this study. Based on the taxonomy of director roles proposed by Hillman et al. (2000), IE are current and former female senior officers who provide the company with their 
professional background, experiences, advice, and alternative positions about internal business affairs (Markarian and Parbonetti, 2007; Hillman et al., 2000). The ADV group is made up of professionals specialized in individual fields, such as law, finance, or marketing, among others, who offer companies their knowledge and expertise (Hillman et al., 2000). Finally, CL are nonexecutive directors who can be classified as politicians, heads of non-profit foundations, clerics, and other public celebrities who bring reputation opportunities and networking to the firm (Hillman et al., 2000).

\subsubsection{Control variables}

We control for individual characteristics shown to be influential in our dependent variable. Board of director size (BoardSize) is the number of directors serving on a board (Jizi 2017). The logarithm of the total assets is used to measure company size (Size) (McGuinness et al., 2017). Ownership concentration (OwnConc) is proxied as the percentage of shares held by the largest and second largest shareholders (Ghazali, 2007). CEO Duality (Duality) is a dummy variable coded 1 if the CEO is also the chairperson and zero otherwise (Michelon and Parbonetti, 2012; Arayssi et al., 2016). Return on assets (ROA) is our measure of profitability. It is the quotient between the earnings before taxes and total assets (García-Meca and PuchetaMartínez, 2018). The leverage ratio (Leverage) is the total debt scaled by total assets (Michelon et al., 2015). The board meetings variable (Bmeetings) is the number of board meetings held per year in the company (Haslinda et al., 2016). Additionally, we control for firm age (Firm_Age), measured by the years a firm has been in existence (Amato \& Falivena, 2019). The Herfindahl-Hirshman Index (Competitiveness) is used to measure industry competitiveness. A positive relationship between CSR and competitiveness is expected (Battaglia et al., 2014; Luo \& Du, 2015). Based on Borghesi et al. (2014), the index indicates 
the extent to which the sales of a given firm within a particular industry are dominated by a single firm:

$$
\text { Herfindahl }=\frac{\sum \text { Sales }_{F}^{2}}{\left(\sum \text { Sales }_{F}\right)^{2}}
$$

Ranging from 0 to 1 , lower levels mean many competitors, and higher values indicate higher market concentration and monopoly power as well as decreased competitiveness (Borghesi et al., 2014). The Ibex35 is the benchmark stock market index of the Spanish capital markets, representative of Spanish economic development. It includes the largest 35 Spanish companies quoted on the stock market (Sierra et al., 2013). It is considered a dummy variable that equals 1 if the company is listed on the Ibex-35 index and 0 otherwise (Gallego-Álvarez et al., 2010; García-Sánchez, 2008; Odriozola and Baraibar-Diez, 2017).

Finally, a set of dummy variables to control for industry $\left(\rho_{i}\right)$ and year effects $\left(\mu_{t}\right)$ are included in the models.

\subsection{Econometric model}

In order to check the above hypotheses, the following regression model can be constructed:

$$
\mathrm{CSR}_{\mathrm{it}}=\beta_{0}+\beta_{1} \mathrm{CSR}_{\mathrm{it}-1}+\beta_{2} \% \mathrm{IE}_{\mathrm{it}}+\beta_{3} \% \mathrm{ADV}_{\mathrm{it}}+\beta_{4} \% \mathrm{CL}_{\mathrm{it}}+\beta_{5} \text { BoardSize }_{\text {it }}+\beta_{6} \text { Size }
$$

${ }_{\text {it }}+\beta_{7}$ OwnConc $_{\text {it }}+\beta_{8}$ Duality $_{\text {it }}+\beta_{9}$ ROA $_{\text {it }}+\beta_{10}$ Leverage $_{\text {it }}+\beta_{11}$ Bmeeting $_{\text {it }}+\beta_{12}$ Ibex $35_{\text {it }}++$ $\beta_{13}$ Competitiveness $_{\text {it }}+\beta_{14}$ Firm_Age $_{\text {it }}+\sum \beta_{\mathrm{j}}$ industry $_{\mathrm{i}}+\sum \beta_{\mathrm{K}}$ year $_{\mathrm{t}}+\eta_{\mathrm{i}}+\mu_{\mathrm{it}}$

Endogeneity concerns are frequent in empirical analysis due to the correlation between explanatory variables and error terms. This leads to biased and unreliable results. Previous empirical literature indicates the possible existence of endogeneity problems in the study of CSR and corporate governance due to the fact that both practices are influenced by unobservable firm-specific heterogeneities (Wooldridge, 2010), which through an ordinary 
least squares regression analysis is difficult to identify. According to Dang et al., (2018), there are several econometric techniques to deal with endogeneity issues, with Generalized Method of Moments (GMM) considered to be more reliable than the others, because it has extreme effects for coefficient correction.

For this reason, we use a dynamic GMM panel estimator (Arellano and Bond, 1991; Blundell and Bond, 1998) for our empirical research which requires considering the individual (i) and the point in time (t). Additionally, the error term is decomposed into the stochastic error term, varying the cross-time and cross-section combined effect $\left(\mu_{\mathrm{it}},\right)$, and the unobserved timeinvariant, firm-specific effect $\left(\eta_{i}\right)$ which varies among individuals, but is constant over time. Unlike many other techniques, it is considered to be highly consistent and efficient because it controls for the three sources of endogeneity; namely, unobserved heterogeneity, simultaneity, and dynamic endogeneity (Wintoki et al., 2012), by modeling it as an individual effect, $\eta$ i, which is then eliminated by taking the first differences of the variables. It arises because of the particular behavior pattern generated when the decision of disclosing CSR information is taken by specific individuals within a firm (Martínez-Ferrero and García-Sánchez, 2014). Moreover, this technique allows us to control the dynamics of the process by using lagged values of the variables (Wintoki et al., 2012).

A correlation test order $\mathrm{i}\left(\mathrm{m}_{2}\right)$ to check the second-order serial correlation in the firstdifference residuals is used (Arellano and Bond, 1991). As shown in the following tables (Tables 3 and 4), this hypothesis is always rejected. Furthermore, the Hansen test of overidentifying restrictions is applied, which confirms the rightness of the instruments used in the estimation. The Wald test (z) confirms the joint significance of the coefficients and of the time dummies. 


\section{RESULTS}

\subsection{Descriptive Statistics}

Table 1, Panel A shows the annual percentage of independent and institutional women directors in our sample (2008-2014). As can be seen, the percentage is growing every year, probably due to the Conthe Code (2006), the first Governance Code that explicitly includes a recommendation on gender diversity.

Panel B reports the descriptive statistics for all the variables used in the regression models. When our dependent variable, CSR disclosure (CSR), is described, it is indicated that the CSR index is constructed by the aggregation of the 6 items analyzed. The following classification can be used to determine the level of CSR disclosure of the companies in our sample: a CSR index of 0 shows that company CSR disclosure is null, a CSR index between 0.1 and 2.5 shows that company CSR disclosure is moderate, a CSR index between 2.6 and 4.9 shows that company CSR disclosure is high, and a CSR index of 5 shows that company CSR disclosure is complete regarding 5 out of 6 items explored in our CSR index. As appreciated in Panel B, our CSR index ranges from 0 (minimum) to 5 (maximum) and is, on average, 0.956 out of 5. This figure suggests that, on average, the level of CSR disclosure of firms in our sample is moderate. This leads us to conclude that Spanish firms should improve CSR disclosure since this value is far from 5. Regarding board composition, on average, the largest represented group is ADV, followed by IE and CL. The average value of board director size is 10.312 members, with 21 members for the largest board. Company size expressed in thousands of euros, is 13.157. Ownership concentration (OwnConc) is $42.9 \%$; Leverage and ROA are $75.5 \%$ and $39.8 \%$, respectively. $36.9 \%$ of the CEOs are also the chairperson of the board (duality), $18.6 \%$ of the companies are listed on the Ibex35 index, 3.684 is the mean age of companies and 9.917 is the average number of annual meetings, ranging from 2 to 28 . Finally, the mean of the 
Competitiveness variable is 0.035 , which indicates that the companies in our sample live in a competitive environment.

\section{Insert table 1 about here}

Moreover, Table 2 indicates that all the variables present low correlation coefficients $<0.80$ ), thereby confirming that multicollinearity should not be a concern.

\section{Insert table 2 about here}

\subsection{Univariate Results}

For an exploratory analysis, in Table 3, we divide the sample into two groups depending on the presence of female board members classified as industry experts, advisors, or community leaders. Then, in Panel A, we conduct a test of means comparison to explore whether firm CSR disclosure is different between the different groups, supporting the influence of the three categories of female directors.

In panel B, we present the univariate Student t-test. It identifies statistically significant differences in means between firms where gender diversity is present and firms where it is not. Gender diversity boards are those in which there is at least one woman on the board. NonGender diversity boards include those in which there is no woman. The evidence indicates that boards with gender and non-gender diversity differ to a statistically significant extent across the main variables of our study $(\mathrm{p}<0.01)$. Particularly, we would like to note that the mean CSR of non-gender diverse boards is higher than the mean CSR of gender-diverse boards and is statistically significant. Female directors on boards in our sample are classified into industry experts, advisors and influential, who have different interests, aims and orientations toward CSR issues. This could lead to power struggles among them affecting negatively the disclosure of CSR information in comparison to boards made up only by male directors, who show the 
same positive attitude toward the reporting of CSR information. It seems that male directors on boards tend to align regarding CSR matters, which may be the result of a power alliance existing among them.

\section{Insert table 3 about here}

\subsection{Regression results}

Table 4 provides the estimates for our main hypothesis. Models 1, 2, and 3 measure the effect of the women directors classified as industry experts (IE), advisors (ADV), and community leaders (CL) on corporate social responsibility disclosure.

Model 1 results do not support hypothesis 1 regarding the positive effect of industry expert female directors on CSR disclosure. According to the results, the fact that women are industry experts does not lead to a higher disclosure of CSR information. Therefore, when female directors sit on boards as previous executives of firms from similar industries, they provide past expertise, capabilities, and professional background acquired in other companies as executives, but our findings note that this does not guarantee that their attitude toward CSR is going to be different with respect to the rest of female directors. This could be explained by their previous roles as CEOs or managers of similar firms. When females reach these usually "male executive positions", they may possess attributes that do not differ from their male colleagues, so that when they break the glass ceiling and adapt to a male-dominated culture, some features such as their predisposition toward CSR disclosure may vanish.

Model 2 presents a positive and significant relationship between women board advisors and CSR disclosure, confirming that the positive influence of female advisors on boards is translated into a higher probability of CSR information being disclosed (Prado-Lorenzo et al., 2009). Therefore, according to our results, the human capital of advisory female directors already has a positive effect on strategic decisions like CSR disclosure. These female directors, who act as decision supporters, usually possess expertise, knowledge, and occupational 
backgrounds relative to non-markets and non-business areas, which favors their orientation toward social and environmental issues and their increased preference for CSR matters. Thus, the higher specific ability of women in social relations and their larger commitment and engagement with the needs and demands of others are more remarkable when females act as advisor directors.

In model 3, we see a reversed relationship, where the proportion of women community leaders CL members is negatively linked to CSR disclosure. This confirms our Hypothesis 3. The members of this group do not usually have previous business experience, and they often sit on boards as a continuation of their careers as community influentials. As we previously noted, in most Spanish boards, directors serving as community influentials have been politicians or still have personal ties with political parties. We observe that when women directors were previously politicians or even members of well-known communities, they may behave opportunistically with the main aim of fulfilling their self-interest and private agendas, avoiding the disclosure of competitive advantages to competitors. Our results suggest that these female directors may be more interested in maintaining their reputation and preserving the competitive advantages of firms, or they may even feel that they are not as pressured by the market to be transparent because of their connections. We think that this feeling of preserving competitive advantages or the relevance given to their connections overtake the expected positive female attitude toward greater CSR disclosure. Although we do not really expect different behavior between men and women CL with respect to CSR disclosure, we already find a different attitude of CL women in relation to the rest of female directors, especially with respect to those who act as advisors and decision supporters (ADV), who already have a positive influence on CSR disclosure.

Model 4 tests a global model including all the types of women directors. It confirms previous results. 
With regard to the control variables, in the general model, the variables Ibex 35, ROA, Leverage, Size, Bmeetings, and Competitiveness present a positive and significant sign, as expected. These results also note that larger companies, leveraged, with big boards, and those with high returns on assets, and that are operating in a highly competitive market, present a positive effect on CSR disclosure. The opposite effect is presented for the remaining control variables.

In addition to the above, the highest Variance Inflation Factor (VIF) for each independent variable included in our model is 2.05 , so we confirm that our model is not skewed due to multicollinearity (Kutner et al., 2005)².

\section{Insert table 4 about here}

\subsection{Additional Analysis}

In this section, we test the moderating effect of female power under the premise that women exhibit greater influence on CSR disclosure when they have a large shareholding position. To test our Hypothesis 4, a moderator variable (female power) is generated. Female Power (PowerF) is a dummy variable equal to 1 if the ratio of the total number of female institutional directors to the total number of directors on board takes a value higher than its mean value and 0, if otherwise. Based on previous literature (López-Iturriaga et al., 2015; García-Meca and Pucheta-Martínez, 2018), institutional directors are those appointed by institutional investors who represent insurance and banking firms or investment funds. These directors are highly relevant in Spain and other civil-law countries, where they represent a significant category of board directors along with internal, independent, and executives.

In this respect, we regress our dependent variable on the directors' classification and the interaction between these variables to examine the moderator effect, as follows:

\footnotetext{
${ }^{2}$ Since the variance inflation factor (VIF) statistics are employed in ordinary least squares (OLS) linear models, our estimations for VIF are obtained by estimating the final model using linear regression (Orser et al., 2010)
} 
$\mathrm{CSR}_{\text {it }}=\delta_{0}+\delta_{1} \mathrm{CSR}_{\mathrm{it}-1}+\delta_{2} \% \mathrm{IE}_{\text {it }}+\delta_{3} \% \mathrm{ADV}_{\text {it }}+\delta_{4} \% \mathrm{CL}_{\text {it }}+\delta_{5}$ PowerF $_{\text {it }}+\delta_{6}$ PowerF $^{*} \mathrm{IE}_{\text {it }}+\delta_{7}$ PowerF*ADV $^{*}+\delta_{8}$ PowerF* $^{*} L_{\text {it }}+\delta_{9}$ Size $_{\text {it }}+\delta_{10}$ BoardSize $_{\text {it }}+\delta_{11}$ OwnConc $_{\text {it }}+\delta_{12}$ Duality $_{\text {it }}+\delta_{13}$ ROA $_{\text {it }}+\delta_{14}$ Leverage $_{i t}+\delta_{15}$ Bmeeting $_{\text {it }}+\delta_{16}$ Ibex35 it $+\delta_{17}$ Competitiveness $_{i t}+\delta_{18}$ Firm_Age $_{i t}+\sum \delta_{\mathrm{j}}$ industry $_{\mathrm{i}}+\sum \delta_{\mathrm{K}}$ year $_{\mathrm{t}}+\eta_{\mathrm{i}}+\mu_{\mathrm{it}}$

Table 5 presents the results of the new GMM regression analysis. In Model 1, we report that the effect of the interaction between PowerF and IE does not have a significant influence on CSR reporting. The results in Model 2 show that female directors with specific knowledge (ADV) do not have a stronger effect on CSR disclosure if there is high institutional female power on the board. In other words, the positive effect of ADV on CSR reporting is weaker in the presence of female institutional power, which suggests a substitutive role of female institutional directors in firms with a high presence of female advisor directors, and not a complementary role, as we expected.

With respect to CL, Model 3 shows the negative effect that CL has on CSR reporting changes, demonstrating that this negative relationship is weaker for firms with high-powered women. This suggests that the presence of female institutional power weakens (and substitutes) the negative effect of female politician directors. This can be explained by the stewardship role played by institutional directors, their long-term perspective, and their objective of protecting the interests of the investors they represent. Therefore, with the negative effect of female influential directors on CSR disclosure, female institutional directors compensate that effect and promote disclosure through their influence in the board decision-making process.

Insert table 5 about here 


\subsection{Robustness Tests}

In order to check the robustness of our model, an alternative proxy for the dependent variable is created. To do so, we use the Corporate Reputation Business Monitor (Merco), which analyzes the Spanish companies with the best practices in social responsibility and good corporate governance through the Merco Responsibility and Corporate Governance Ranking, used in previous research (Ramón-Llorens et al., 2018).

It is based on the opinion of executives, experts from different areas (social responsibility, financial analysts, economic journalists, governmental authorities, NGOs, unions and consumers associations, influencers and social media managers, among others), and citizens. The reports collect and analyze evaluations from the different interest groups in order to diagnose the dimensions measured. Additionally, this study is audited by an external company. The top firm in the ranking receives a maximum score of 10,000 points, while the bottom one receives a maximum value of 3,000 points. In order to reduce difficulties in the interpretation of the results, the scores have been divided by 1,000 .

Based on this index, we create a new variable (newCSR), which takes the value given by the Merco-Responsibility and Corporate Governance rank and 0 otherwise.

Table 6 reports the results of our analysis. It confirms our previous results, ratifying the positive impact of female IE and ADV and the negative influence of female CL directors on CSR reporting, independent of the variable used.

\section{Insert table 6 about here}

We have also estimated the model using an alternative proxy for our dependent variable: the logarithmic transformation of the CSR index. Our findings, not provided for the sake of brevity, are robust to this alternative measure. 


\section{CONCLUSIONS}

This study provides empirical evidence to the scarcely-studied area of human and social capital of female directors' roles in CSR disclosure, providing an alternative view of the role of women in corporate board effectiveness.

Based on the Hillman et al. (2000) taxonomy of board members, we have classified female outside directors into three categories (industry experts, advisors, and community leaders) in order to analyze whether professional experience, technical expertise, or the connections of female directors influence greater disclosure of CSR information. We also examine the moderating role of female power, assuming that it can highly condition female influence over team decisions.

Our results confirm that the technical expertise and specific skills of female advisor directors favor greater orientation toward stakeholders and social issues, and lead them to support the disclosure of CSR matters. However, our findings also confirm the two-sided nature of gender diversity, noting that females with political and social connections do not contribute to increased CSR transparency, but to reducing it. These results can be explained by the interests of these directors in avoiding the disclosure of information that society may perceive negatively, in regards to their behavior, or the reporting of activities that a company's competitors might use to their benefit. The feeling of being more protected and less pressed to be transparent through their connections can also justify the negative influence of female community leaders on CSR disclosure.

Our results confirm the moderating role of female power. The positive effect of advisors and the negative effect of community leader female directors on CSR disclosures are both reduced with the presence of female power in the company, suggesting that the dominating 
owner position of female directors plays a substitutive role and reduces the negative effect of female directors appointed for their technical knowledge or political and social ties.

The results of this study have different practical implications. Recent calls for increasing female board presence can lead to more socially responsible corporations, which has important implications for policy makers and companies interested in the role of women directors (European Commission, 2011). Moreover, our results confirm the importance of appointing female board members with specific knowledge and technical qualifications, especially in the context of current governance scandals and increasing criticism over opacity and lack of transparency in social and environmental activities. Our findings also provide important implications for countries with a widespread presence of connections between firms and politicians. In these countries, investors, stakeholders, and regulatory authorities are generally interested in increasing transparency, so they should recommend the reporting of the political connections of board members in governance reports, as this information can condition CSR reporting. Finally, this paper suggests the importance of not considering all women directors as a homogeneous group and exploring the influence of these factual faultlines (experience and power) on CSR disclosure.

This study also shows a more precise process for understanding CSR disclosure strategy and its interrelations with board gender diversity and female power. Thus, our research has practical merit, as it helps firms, managers, shareholders, investors, and stakeholders analyze how female directors impact on CSR disclosure in a different way; according to their experience, expertise, and political ties. From our results, stakeholders can understand how firms with diverse boards behave towards CSR disclosure and meet their social and environmental demands. However, they must also be aware that firm orientation towards their CSR demands also depends on female power. Therefore, this study is relevant for managers and owners by showing that there may be strategic reasons to consider not just appointing 
qualified women directors, but also appointing them to powerful positions (i.e. as institutional directors) in order for them to be more influential in strategic decisions such as CSR disclosure.

The results of this study should be interpreted carefully, since this research is subject to certain limitations. First, one limitation of this research is our proxy of CSR. Despite believing this measure to be reliable and tested in other studies (e.g. Prado Lorenzo et al., 2009; GarcíaMeca and Pucheta-Martínez, 2018), we should be cautious about the possible bias it includes because the final assessment is conditioned by the person who processes the information. Moreover, it is a fact that when working with binary information, indicators do not take the quality of the information into account and only measure the quantity of disclosure (Leitoniene and Sapkauskiene, 2015). However, some items that we have included to create the index, such as whether the CSR information is audited by an external and independent entity, allow companies to enhance the quality and reliability of the information provided and enhances stakeholders' engagement process. Notwithstanding, we must say that our results are robust to alternative proxies of CSR based on the Merco Corporate Reputation Business Monitor (Merco), which analyzes the Spanish companies with the best practices in social responsibility and good corporate governance. The classification of outside directors can also be considered to be a limitation of the study. It has been based on the biographical information available, so once again, the final classification of each director depends on the person who processes the information. For future research, more evidence examining the implications, motivations, and effects of these categories of directors on firm outcomes would be useful to better understand the role of women directors in the governance and reporting strategies of companies. Moreover, although data were collected in Spain, which limits the possibility of generalizing our results, this also opens up promising avenues for future international studies. Therefore, we recommend researchers explore our evidence in international samples as well as with non-listed and small and medium-sized firms. 


\section{References}

Adams, R. B., (2016), "Women on Boards: The Superheroes of Tomorrow?" European Corporate Governance Institute (ECGI) - Finance Working Paper (No. 466/2016); FIRN Research Paper N. 2696804. Available at SSRN: https://ssrn.com/abstract=2696804 or http://dx.doi.org/10.2139/ssrn.2696804

Adams, R.B., and Ferreira, D. (2009), "Women in the boardroom and their impact on governance and performance". Journal of Financial Economics, 94(2), 291-309.

Alonso-Almeida, M.M., Marimon, F., Llach, J., (2015), "Difusión de las memorias de sostenibilidad en Latinoamérica: análisis territorial y sectorial". Estudios Gerenciales, 31(135), 139-149.

Amato, A. D., \& Falivena, C. (2019). Corporate social responsibility and firm value : Do firm size and age matter? Empirical evidence from European listed companies, (July), 1-16. https://doi.org/10.1002/csr.1855

Andrés, P., García-Rodríguez, I., Romero-Merino, M. E., and Santamaría, M. (2018), "Politicization and financial expertise in Spanish savings banks. Patterns in the configuration of their boards". Universia Bussines Review 57, 18-38.

Arayssi, M., Dah, M. and Jizi, M. (2016), "Women on boards, sustainability reporting and firm performance”. Sustainability Accounting, Management and Policy Journal 7 (3), 376 401.

Arellano, M., \& Bond, S., (1991), "Some Tests of Specification for Panel Data: Monte Carlo Evidence and an Application to Employment Equations". The Review of Economic Studies, 58(2), 277-297. http://doi.org/10.2307/2297968

Battaglia, M., Testa, F., Bianchi, L., Iraldo, F. and Frey, M. (2014). Corporate Social Responsibility and Competitiveness within SMEs of the Fashion Industry: Evidence from Italy and France. Sustainability 6, 872-893. doi:10.3390/su6020872

Baysinger, B. D., \& Zardkoohi, A., (1986), "Technology, residual claimants and corporate control". Journal of Law, Economics, and Organization, 2 (2), 339-344.

Baysinger, B., \& Butler, H., (1985), "Corporate governance and the board of directors. Performance effects of changes in board composition". Journal of Law, Economics, and Organization, 1, 101-124.

Bear, S., Rahman, N., Post, C., (2010), "The Impact of Board Diversity and Gender Composition on Corporate Social Responsibility and Firm Reputation". Journal of Business Ethics, 97(2), 207-221.

Ben Barka, H., \& Dardour, A., (2015), "Investigating the relationship between director's profile, board interlocks and corporate social responsibility". Management Decision, 53, 553-570.

Bezrukova, K., Jehn, K. A., Zanutto, E., \& Thatcher, S. M. B., (2009), "Do workgroup faultlines help or hurt? A moderated model of faultlines, team identification and group performance". Organization science, 20, 35-50

Birkey, R., Michelon, G., Patten, D., \& Sankara, J. (2016). Does assurance on CSR reporting enhance environmental reputation? An examination in the U.S. context. Accounting Forum, 40, 143-152.

Blundell, R., \& Bond, S., (1998), "Initial conditions and moment restrictions in dynamic panel data models". Journal of Econometrics, 87(1), 115-143. http://doi.org/10.1016/S03044076

Bona-Sánchez, C., García-Meca, E., \& Pérez-Alemán, J., (2018), "Earnings informativeness and institutional investors on boards". Revista de Contabilidad - Spanish Accounting Review, 21 (1), 73-81.

Bona-Sánchez, C., Pérez-Alemán, J., \& Santana-Martín, D. J., (2014), “Politically connected 
firms and earnings informativeness in the controlling versus minority shareholders context: European evidence". Corporate Governance: An International Review, 22(4), 330-346. http://doi.org/10.1111/corg.12064.

Bonsón, E. and Bednárová, M. (2015). CSR reporting practices of Eurozone companies. Revista de Contabilidad-Spanish Accounting Review, 18 (2), 182-193. DOI: 10.1016/j.rcsar.2014.06.002

Borghesi, R., Houston, J. F., \& Naranjo, A., (2014), "Corporate socially responsible investments: CEO altruism, reputation, and shareholder interests". Journal of Corporate Finance, 26, 164-181. http://doi.org/10.1016/j.jcorpfin.2014.03.008

Braiotta, L., Jr., \& Sommer, A. A., (1987), "The essential guide to effective corporate board committees" (Prentice-Hall, Englewood Cliffs, NJ).

Chaney, P. K., Faccio, M., Parsley, D., Chaney, P., \& Parsley, D., (2011), "The Quality of Accounting Information in Politically Connected Firms Connected Firms". Journal of Accounting and Economics, 51, 58-76.

Che, L., \& Zhang, P., (2017), "The impact of family CEO's ownership and the moderating effect of the second largest owner in private family firms". Journal of Management \& Governance, 21(3), 757-784.

Chen, H-L., (2014), "Board capital, CEO power and R\&D investment in electronics firms". Corporate Governance: An International Review, 22(5), 422-436.

Chen, S., Sun, Z., Tang, S., \& Wu, D., (2011), "Government intervention and investment efficiency: Evidence from China". Journal of Corporate Finance, 17(2), 259-271.

Cornett, M. M., Marcus, A. J., Saunders, A., \& Tehranian, H., (2007), "The impact of institutional ownership on corporate operating performance". Journal of Banking and Finance, 31(6), 1771-1794. http://doi.org/10.1016/j.jbankfin.2006.08.006

Cuadrado-Ballesteros, B., Martínez-Ferrero, J., \& García-Sánchez, I.M., (2017), "Board structure to enhance social responsibility development: a qualitative comparative analysis of US companies". Corporate Social Responsibility and Environmental Management, 24 (6), 524-542.

Daily, C.M., \& Johnson, J.L., (1997), "Sources of CEO power and firm financial performance: a longitudinal assessment". Journal of Management, 23 (2), 97-117.

Dang, C., Li, Z.F. \& Yang, C. (2018). "Measuring firm size in empirical corporate finance". Journal of Banking and Finance, 86, 159-176.

Dang, R., Bender, A.F., \& Scotto, M.J., (2014), "Women on French corporate board of directors: How do they differ from their male counterparts?" The Journal of Applied Business Research, 30(2), 489-508.

Dass, N., Kini, O., Nanda, V., Onal, B., \& Wang, J., (2014)," Board expertise: Do directors from related industries help bridge the information gap?" Review of Financial Studies, 27(5), 1533-1592.

Davis, M.H., Capobianco, S., \& Kraus, L.A., (2010), "Gender differences in responding to conflict in the workplace: Evidence from a large sample of working adults". Sex Roles, $63,500-514$.

European Commission, (2011), "The EU corporate governance framework". Green Report.

Faleye, O., Hoitash, R., \& Hoitash, U., (2014), "Industry expertise on corporate boards. Northeastern U. D’Amore-McKim”. School of Business. Research Paper.

Fuente, J. A., García-Sánchez, I. M., \& Lozano, M. B. (2017). The role of the board of directors in the adoption of GRI guidelines for the disclosure of CSR information. Journal of Cleaner Production, 141, 737-750. https://doi.org/10.1016/j.jclepro.2016.09.155

Galbreath, J., (2016), "When do board and management resources complement each other?. A study of effects on corporate social responsibility". Journal of Business Ethics, 136, 281292. 
Gallego-Álvarez, I., García-Sánchez, I. M., \& Rodríguez-Domínguez, L., (2010), “The influence of gender diversity on corporate performance". Spanish Accounting Review, 13(1), 53-88

García-Meca, E., \& Pucheta-Martínez, M.C., (2018), "How institutional investors on boards impact on stakeholder engagement and corporate social responsibility reporting". Corporate Social Responsibility and Environment Management, 25 (3), 237-249. https://doi.org/10.1002/csr.1451.

García-Sánchez, I.M., (2008), “Corporate social reporting: segmentation and characterization of Spanish companies". Corporate Social Responsibility and Environmental Management, 15 (4), 187-198. http://doi.org/10.1002/csr.141

Ghazali, N. A. M., (2007), "Ownership structure and corporate social responsibility disclosure: Some Malaysian evidence”. Corporate Governance, 7 (3), 251-66.

Giannarakis, G., (2014), "The determinants influencing the extent of CSR disclosure". International Journal of Law and Management, 56(5), 393-416.

Guizani, M., (2013), "The Moderating effect of large shareholders on board structure-Firm performance relationship: An agency perspective". Journal of Poverty, Investment and Development, 2, 64-73.

Hambrick, D., \& Mason, P., (1984), "Upper echelons theory: The organization as a reflection of its top managers". Academy of Management Review, 9, 193-343.

Harjoto, M.A., Laksmana, I., \& Lee, R., (2015), "Board diversity and corporate social responsibility". Journal of Business Ethics, 132(4), 641-660.

Harrigan, K.R., (1981), "Numbers and positions of women elected to corporate boards". Academy of Management Journal, 24(3), 619-625.

Haslinda, Y., Alia D, J., \& Faizah, D., (2016), "Corporate Governance and Corporate Social Responsibility Disclosures: An Emphasis on the CSR Key Dimensions". Journal of Accounting and Auditing: Research \& Practice, 2016, 1-14. http://doi.org/10.5171/2016.476550

Haynes, K. T., \& Hillman, A., (2010), "The effect of board capital and CEO power on strategic change". Strategic Management Journal, 31(11), 1145-1163.

Helfaya, A., \& Moussa, T. (2017). Do Board's Corporate Social Responsibility Strategy and Orientation Influence Environmental Sustainability Disclosure? UK Evidence. Business Strategy and the Environment, 26(8), 1061-1077. https://doi.org/10.1002/bse.1960

Hillman, A. J., \& Dalziel, T., (2003), "Boards of directors and firm performance: Integrating agency and resource dependence perspectives". Academy of Management Review, 28(3), 383-396.

Hillman, A., Cannella, J., \& Paetzold, R. (2000). The resource dependence role of corporate directors: strategic adaptation of board composition in response to environmental change. Journal of Management ..., 37(March), 235-256. https://doi.org/DOI: 10.1111/14676486.00179

Hillman, A., Cannella, J., \& Paetzold, R., (2000), “The resource dependence role of corporate directors: strategic adaptation of board composition in response to environmental change". Journal of Management, 37, 235-256. http://doi.org/DOI: 10.1111/1467-6486.00179

Hillman, A.J., \& Cannella, A.A. Jr., Harris, I.C., (2002), "Women and racial minorities in the boardroom: How do directors differ?" Journal of Management, 28(6), 747-763. https://doi.org/10.1016/S0149-2063(02)00192-7

Jain, T., \& Jamali, D., (2016), The Effect of Corporate Governance on Corporate Social Responsibility". Corporate Governance-an International Review, 45(1), 102-123.

Jizi, M., (2017), "The influence of board composition on sustainable development disclosure". Business Strategy and the Environment, 26 (5), 640-655. https://doi.org/10.1002/bse.1943

Kayser, S. A., Toffel, M. W., \& Maxwell, J. W. (2014), "Is there a cost to joining a 
'free'voluntary program? The role of stakeholder scrutiny". In Sixth Annual ARCS Research Conference, New York.

Kesner, I.F., (1988), "Directors' characteristics and committee membership: An Investigation of Type, Occupation, Tenure, and Gender". The Academy of Management Journal, 31 (1), 66-84. DOI: $10.2307 / 256498$

Kim, H., (2013), "Glass fence thicker than glass ceiling: The puzzling gaps of women's leadership in Korea". In J. Rajasekar (Ed.), Culture and gender in leadership: Perspectives from the Middle East and Asia (pp. 253-274). Hampshire, England: Palgrave Macmillan.

Konrad, A., Steurer, R., Langer, M. E., \& Martinuzzi, A., (2006), "Empirical findings on business-society relations in Europe". Journal of Business Ethics, 63, 89-105.

Kor, Y., \& Sundaramurthy, C., (2009), "Experience-based human capital and social capital of outside directors". Journal of Management, 35(4), 981-1006.

Kutner, M.H., Neter, J., Nachtsheim, C.J., \& Li, W., (2005), “Applied Linear Statistical Models". McGraw Hill, New York.

Landry, E.E., Bernardi, R.A., \& Bosco, S.M., (2016), "Recognition for sustained corporate social responsibility: female directors make a difference". Corporate Social Responsibility and Environmental Management 23(1), 27-36.

Lau D.C., \& Murnighan, J.K., (1998), "Demographic diversity and faultlines: the compositional dynamics of organizational groups". Academy of Management Review 23(2), 325-340.

Lau D.C., \& Murnighan, J.K., (2005), "Interactions within groups and subgroups: The effects of demographic faultlines". Academy of Management Journal, 48(4), 645-659.

Leitonienea, S., \& Sapkauskiene, A., (2015), "Quality of corporate social responsibility information". Procedia - Social and Behavioral Sciences, 213, 334-339

Li, H., Meng, L., Wang, Q., \& Zhou, L.A., (2008), "Political connections, financing and firm performance: Evidence from Chinese private firms". Journal of Development Economics, 87(2), 283-299.

Li, J., \& Hambrick, D. C., (2005), "Factional groups: A new vantage on demographic faultlines, conflict, and disintegration in work teams". Academy of Management Journal, 48 (5), 794 813. https://doi.org/10.5465/AMJ.2005.18803923

López-Iturriaga, F., García-Meca, E., \& Tejerina-Gaite, F., (2015), "Institutional directors and board compensation: Spanish evidence”. BRQ Business Research Quarterly, 18(3), 161173. http://doi.org/10.1016/j.brq.2014.07.003

Luo, X., \& Du, S. (2015). Exploring the relationship between corporate social responsibility and firm innovation, 703-714. https://doi.org/10.1007/s11002-014-9302-5

Mallin, C. A., \& Michelon, G., (2011), "Board reputation attributes and corporate social performance: An empirical investigation of the US Best Corporate Citizens". Accounting and Business Research, 41(2), 119-144.

Markarian, G., \& Parbonetti, A., (2007), "Firm Complexity and Board of Director Composition". Corporate Governance: An International Review, 15(6), 1224-1243.

Marquis, Ch., Toffel, M.V., \& Zhou, Y. (2016), "Scrutiny, norms, and selective disclosure: A global study of greenwashing", Organization Science 27(2), 483-504.

Martínez-Ferrero, J., \& García-Sánchez, I. M., (2014), "Is corporate social responsibility an entrenchment strategy? Evidence in stakeholder protection environments". Review of Managerial Science, 1-26. http://doi.org/10.1007/s11846-014-0120-1

Mavin, S., Bryans, P., \& Cunningham, R., (2010), "Fed-up with blair's babes, gordon's gals, cameron's cuties, nick's nymphets". Gender in Management, 25(7), 550-569.

McGuinness, P. B., Vieito, J. P., \& Wang, M. (2017), "The role of board gender and foreign ownership in the CSR performance of Chinese listed firms". Journal of Corporate Finance, 42, 75-99.

Michelon, G. \& Parbonetti, A. (2012), "The effect of corporate governance on sustainability 
disclosure", Journal of Management and Governance, vol. 16, no. 3, pp. 477509. https://doi.org/10.1007/s10997-010-9160-3

Michelon, G., Pilonato, S., \& Ricceri, F., (2015), "CSR reporting practices and the quality of disclosure: An empirical analysis". Critical Perspectives on Accounting, 33, 59-78

Nekhili, M., \& Gatfaoui, H., (2013), "Are demographic attributes and firm characteristics drivers of gender diversity? Investigating women's positions on French boards of directors". Journal of Business Ethics, 118(2), 227-249.

Nielsen, S.T., \& Huse, M., (2010), "The contribution of women on boards of directors: Going beyond the surface". Corporate Governance: An International Review, 18(2), 136-148.

Odriozola, M. D., \& Baraibar-Diez, E., (2017), "Is Corporate Reputation Associated with Quality of CSR Reporting? Evidence from Spain". Corporate Social Responsibility and Environmental Management, 24(2), 121-132. http://doi.org/10.1002/csr.1399

Oh, W-Y, Cha, J., \& Chang, Y.K., (2017), "Does ownership structure matter?. The effects of insider and institutional ownership on corporate social responsibility". Journal of Business Ethics, 146, 111-124.

Orser, B., Martine, S., Riding, A. \& Carrington, C. (2010). "Gender and Export Propensity". Entrepreneurship Theory and Practice, 34(5), pp. 933-957. doi: 10.1111/j.15406520.2009.00347.x.

Ortiz-de-Mandojana, N., Aragón-Correa, J. A., Delgado-Ceballos, J., \& Ferrón-Vílchez, V., (2012), "The effect of director interlocks on firms' adoption of proactive environmental strategies". Corporate Governance: An International Review, 20, 164-178.

Pearsall, M. J., Ellis, A. P. J., \& Evans, J. M., (2008), "Unlocking the Effects of Gender Faultlines on Team Creativity: Is Activation the Key?" Journal of Applied Pyschology, 93(1), 225-234. http://doi.org/10.1037/0021-9010.93.1.225

Pechersky, A., (2016), "Diversity in board of directors: Review of diversity as a factor to enhance board performance". Studia commercialia Bratislavensia, 9(33), 88-101.

Peterson, C.A., \& Philpot, J., (2007), "Women's role on U.S. Fortune 500 boards: Directors expertise and committee memberships". Journal of Business Ethics, 72, 177-196.

Pfeffer, J., \& Salancik, G. R., (1978), "The external control of organizations: A resource dependence perspective". New York: Harper and Row.

Prado-Lorenzo, J.-M., Gallego-Alvarez, I., \& Garcia-Sanchez, I. M., (2009), "Stakeholder engagement and corporate social responsibility reporting: The ownership structure effect". Corporate Social Responsibility and Environmental Management, 16(2), 94-107.

Ramón-Llorens, M. C., García-Meca, E., \& Pucheta-Martínez, M. C., (2018), "The role of human and social board capital in driving CSR reporting". Long Range Planning, (in Press) http://doi.org/10.1016/j.lrp.2018.08.001

Rao, K., \& Tilt, C., (2016), "Board diversity and CSR reporting: an Australian study". Meditari Accountancy Research, 24(2), 182-210.

Reid, E. M., \& Toffel, M. W. (2009), "Responding to public and private politics: Corporate disclosure of climate change strategies". Strategic Management Journal, 30 (11), 1157 1178.

Rosener, J.B., (1995), “America's Competitive Secret: Utilizing Women as a Management Strategy". Oxford University Press, New York

Ruigrok, W., Peck, S., \&Tacheva, S., (2007), "Nationality and gender diversity on Swiss corporate boards". Corporate Governance: An International Review, 15(4), 546-557.

Setó-Pamies, D., (2015), "The relationship between women directors and corporate social responsibility”. Corporate Social Responsibility and Environmental Management, 22(6), 334-345.

Shaukat, A., Qiu, Y., \& Trojanowski, G., (2016), "Board Attributes, Corporate Social 
Responsibility Strategy, and Corporate Environmental and Social Performance". Journal of Business Ethics, 569-585.

Shrader, C., Blackburn, V., \& Iles, P., (1997), "Women in management and firm value: An exploratory study". Journal of Managerial Issues, 9, 355-372.

Shropshire, C., (2010), "The role of the interlocking director and board receptivity in the diffusion of practices". Academy of Management Review, 35, 246-264.

Sierra, L., Zorio, A., \&García-Benau, M.A., (2013), "Sustainable development and assurance of corporate social responsibility reports published by Ibex-35 companies". Corporate Social Responsibility and Environmental Management, 20 (6), 359-370. http://doi.org/10.1002/csr.1303

Singh, V., Terjesen, S., \& Vinnicombe, S., (2008), "Newly appointed directors in the boardroom: How do women and men differ". European Management Journal, 26(1), 4858.

Smith, N., \& Parrotta, P., (2018), "Why so few women on boards of directors? Empirical evidence from Danish companies in 1998-2010". Journal of Business Ethics, 147, 445467.

Tate, G., \& Yang, L., (2015), "Female leadership and gender equity: evidence from plant closure". Journal of Financial Economics, 117, 77-97.

Tian, J., Haleblian, J., \& Rajagopalan, N., (2011), "The effects of board human and social capital on investor reactions to new CEO selection". Strategic Management Journal, 32(7), 731-747.

Toffel, M. W. (2005), "Voluntary environmental management initiatives: smoke signals or smoke screens?", Doctoral dissertation, University of California, Berkeley.

Triana, M.C., Miller, T., \& Trzebiatowski, T.M., (2013), "The double-edged nature of board gender diversity: Diversity, firm performance, and the power of women directors as predictors of strategic change". Organization Science, 25, 609-632.

Tsai, W., \& Ghoshal, S., (1998), "Social capital and value creation: The role of intra-firm networks". Academy of Management Journal, 41, 464-476.

Walls, J. L., \& Hoffman, A. J., (2013), "Exceptional boards : Environmental experience and positive deviance from institutional norms". Journal of Organizational Behavior, 271, 253-271.

Wang, J., \& Dewhirst, D. H., (1992), "Board of directors and stakeholder orientation”. Journal of Business Ethics, 11(2), 115-123.

Westphal, J. D., (1999), "Collaboration in the boardroom: Behavioral and performance consequences of CEO-board social ties". Academy of Management Journal, 42, 7-24.

Wintoki, M.B., Linck, J.S. \& Netter, J.M., (2012), "Endogeneity and the dynamics of internal corporate governance". Journal of Financial Economics 105, 581-606.

Wooldridge, J. M. (2010). Econometric analysis of cross section and panel data. MIT Press, Cambridge. 